\title{
KONTROL KONSISTENSI MUTU DAN KANDUNGAN AFLATOKSIN PRODUK KACANG TANAH SANGRAI MELALUI STANDARDISASI PROSES PRODUKSI
}

\section{CONTROL OF QUALITY CONSISTENCY AND AFLATOXIN CONTENT OF ROASTED PEANUT PRODUCT THROUGH PRODUCTION PROCESS STANDARDIZATION}

\author{
Umi Laila, Yuniar Khasanah, Rifa Nurhayati, Dini Ariani, Lusty Istiqomah, \\ Wiwin Widiastuti, Muhamad Kurniadi \\ Balai Penelitian Teknologi Bahan Alam, Lembaga Ilmu Pengetahuan Indonesia \\ Jalan Jogja-Wonosari km 31.5 Desa Gading, Kecamatan Playen, \\ Kabupaten Gunungkidul, Yogyakarta 55861 \\ E-mail: umilaila38@gmail.com
}

Diterima : 08-04-2019

Direvisi : 24-05-2019

Disetujui : 22-07-2019

\begin{abstract}
ABSTRAK
Kacang tanah diolah oleh Usaha Kecil dan Menengah (UKM) Bimaram menjadi kacang tanah sangrai tanpa kulit. Proses produksi kacang sangrai belum merujuk pada suatu Prosedur Operasional Baku (POB). Hal tersebut sangat kontradiktif terhadap keinginan konsumen untuk mendapatkan produk yang konsisten dan stabil dari segi mutu dan keamanan produk. Melalui penelitian ini, disusun POB untuk produksi kacang sangrai. Karakteristik mutu yang meliputi kadar air dan sifat sensoris produk (rasa, aroma, kekerasan) serta titik kritis keamanan produk kacang yang berupa kandungan aflatoksin B1 dievaluasi. POB yang telah disusun diaplikasikan ke UKM Bimaram, yang mencakup alur produksi beserta detail tiap titik prosesnya, spesifikasi bahan dan peralatan, serta sasaran hasil tiap titik proses. Dari penelitian ini, didapatkan bahwa POB yang disusun tidak merubah prosedur produksi yang selama ini dilakukan oleh UKM, POB hanya mencatat prosedur produksi dan menyajikannya lebih sistematis dan terukur standar. Hal ini didukung oleh data kadar air yang didapat pada kacang sangrai sebelum dan setelah diterapkannya POB yang tidak berbeda nyata $(p>0,05)$, berturut-turut sebesar $4,31 \%$ dan $4,58 \%$. Penerapan POB meningkatkan karakteristik sensoris produk kacang sangrai untuk rasa dan kekerasan walaupun tidak signifikan $(p>0,05)$, kecuali aroma yang peningkatannya signifikan $(p<0,05)$. Uji korelasi yang menggambarkan hubungan kadar air dan sifat sensoris terhadap penerapan POB menunjukkan hasil yang serupa. Sementara itu, kandungan aflatoksin B1 pada komoditas kacang mentah, kacang setengah kering, dan kacang sangrai setelah penerapan POB berada di bawah ambang batas yang dipersyaratkan BPOM dan US Food and Drug Administration, yang masing-masing adalah 4,$68 ; 2,78 ; 4,42 \mathrm{ppb}$.
\end{abstract}

Kata kunci: kacang tanah sangrai, prosedur operasional baku, kadar air, sensoris, aflatoksin B1

\begin{abstract}
Peanut has been processed by Bimaram - Small Medium Enterprise (SME) to become roasted shelledpeanut. The production process was not referred to certain Standard Operating Procedure (SOP). It was opposite to consumer desire for obtaining consistent and stable product from quality and safety aspect. Through this research, SOP was arranged. Quality character including moisture content and sensory properties (taste, aroma, and hardness) and also a critical point of the peanut-based product that is aflatoxin $B 1$ were evaluated. Arranged $P O B$ was applied to the $S M E$, include production line with the detail of process unit, material and equipment specification, and targeted outcome based on each process unit. From this research, it can be obtained that arranged SOP has not to change former production process which had been conducted by SME, SOP just records the production process and serves it to be more systematic and standardized measurable. It was revealed by the moisture content of roasted peanut produced before and after SOP applied were non significant different ( $p>0.05)$, i.e.
\end{abstract}

146 Umi Laila, Yuniar Khasanah, Rifa Nurhayati, Dini Ariani, Lusty Istiqomah, Wiwin Widiastuti, Muhamad Kurniadi Kontrol Konsistensi Mutu Dan Kandungan Aflatoksin Produk Kacang Tanah 
$4.31 \%$ and $4.58 \%$ respectively. SOP application improved sensory properties of roasted peanut for taste and hardness although the difference was unsignificant $(p>0.05)$, except aroma in which the improvement was significant $(p<0.05)$. Correlation test depicting the relation of moisture and sensory properties to SOP application showed a similar result. Meanwhile, aflatoxin B1 contents of raw peanut, semi-dried peanut, and roasted peanut after SOP application were beneath acceptable threshold regulated by Indonesia National Agency of Drug and Food Control and also US Food and Drug Administration, i.e. 4.68; 2.78; 4.42 ppb respectively.

Keywords: roasted peanut, standard operating procedure, moisture content, sensory, aflatoxin B1

\section{PENDAHULUAN}

$\mathrm{K}$ acang tanah merupakan tanaman polong-polongan dengan nutrisi yang tinggi, meliputi protein $(25,80 \%)$, lemak (49,24\%), serat $(8,5 \%)$, vitamin, dan mineral (Arya et al., 2016). Kacang tanah juga mengandung omega 3, omega 9, dan beberapa bioaktif, seperti arginin, resveratrol, fitosterol, asam fenolat, dan flavonoid yang mana memiliki peran dalam menurunkan resiko penyakit jantung koroner serta mencegah penyakit kanker (Gama et al., 2018).

Kacang tanah secara dominan diproduksi oleh negara-negara di Asia, dengan Cina dan India menempati peringkat 1 dan 2 (Arya et al., 2016). Sementara, Indonesia sebagai negara agraris menempati urutan kelima terbesar di dunia (Rozalli et al.,2012). Pulau Jawa merupakan daerah produsen kacang tanah terbesar di Indonesia, dengan propinsi DI Yogyakarta memberikan kontribusi 12,46\% dari total produksi nasional (BPS-Statistics Indonesia, 2017). Hal tersebut menjadikan propinsi DI Yogyakarta menempati urutan ketiga produsen kacang tanah terbesar di Indonesia. Berdasarkan data statistik BPS Provinsi DI. Yogyakarta tahun 2018, Kabupaten Gunungkidul merupakan daerah yang mendominasi produksi kacang tanah di DI Yogyakarta dengan kontribusi sebesar 90,44\% (BPS-Statistics of D.I. Yogyakarta Province, 2018).

Cita rasa yang manis pada kacang tanah menyebabkan komoditas ini dapat diaplikasikan sebagai makanan ringan, sebagai komponen pada pembuatan makanan dan kue. Usaha Kecil Menengah (UKM) Bimaram merupakan salah satu UKM di Kecamatan Rongkop, Kabupaten Gunungkidul yang memproduksi pangan olahan berbasis kacang tanah, salah satunya kacang sangrai tanpa kulit, yang mana oleh anggota UKM Bimaram dan masyarakat sekitar dikenal sebagai "kacang oven". Kecamatan Rongkop merupakan salah satu sentra produksi kacang tanah. Namun, terdapat kelemahan yaitu kecamatan Rongkop minim akan ekowisatanya. Meskipun begitu, produk ini berpeluang untuk berkembang besar menjadi salah satu oleh-oleh khas Gunungkidul mengingat kecamatan Rongkop merupakan gerbang wisata Gunungkidul dari arah timur.

Salah satu kendala yang ada di UKM Bimaram adalah belum terdapatnya Prosedur Operasional Baku (POB) atau yang sering disebut Standard Operating Procedure (SOP) dalam proses produksi. Kuantifikasi pada proses produksi masih dilakukan berdasarkan feeling, perkiraan, pengalaman dan belum menggunakan pengukuran yang terstandar, sehingga dimungkinkan kualitas produk tidak konsisten. Pencatatan mengenai alur proses dan analisis komposisi bahan baku juga belum pernah dilakukan. Hal tersebut sangat kontradiktif dengan keinginan konsumen untuk mendapatkan produk yang berkualitas tinggi, konsisten, dan stabil. Konsistensi mutu produk pangan berkaitan dengan kepuasan konsumen, dapat ditinjau dari parameter organoleptik (rasa, tekstur, dan kerenyahan). Untuk mencapai hal tersebut, standardisasi produksi dapat dilakukan.

Selain berkaitan dengan konsistensi mutu produk, standardisasi produk pangan berbasis kacang tanah juga sebaiknya tidak hanya terfokus pada kuantifikasi dan pengukuran yang terstandar, namun juga perlu mempertimbangkan keamanan pangan melalui pengkajian parameter kritis produk berbasis kacang tanah, yaitu kandungan aflatoksin. Aflatoksin adalah 
salah satu mikotoksin yang merupakan hasil metabolit sekunder jamur Aspergillus golongan flavi, terutama $A$. flavus, $A$. parasiticus, A. parvisclerotegenus, A. minisclerotigenes. Aspergillus flavus menghasilkan aflatoksin tipe B1 dan B2 (Udomkun et al., 2017). Sementara, aflatoksin G1 dan G2 dihasilkan oleh Aspergillus tipe lain. Kondisi dan iklim di Indonesia tidak dapat dipungkiri sangat mendukung pertumbuhan jamur Aspergillus, yakni Indonesia beriklim tropis dengan kelembapan udara yang tinggi serta curah hujan yang tinggi (Purwijantiningsih et al., 2005). Meskipun begitu, resiko kesehatan yang berkenaan dengan konsumsi pangan yang mengandung aflatoksin tidak boleh diabaikan, antara lain konsumsi dalam jumlah yang tinggi dapat menyebabkan muntah, sakit perut, bahkan dapat menyebabkan kematian (Mulyati et al., 2013). Terlebih lagi, kuantitas yang rendah namun sering, dapat menginduksi kanker hati (Sherif et al., 2009).

Resiko kesehatan yang diakibatkan oleh aflatoksin tersebut diperparah oleh stabilitas aflatoksin yang juga tinggi. Aflatoksin memiliki sifat tahan terhadap panas dan sulit untuk berubah menjadi senyawa yang tidak beracun (Rahaie et al., 2010). Karena stabilitas aflatoksin yang tinggi tersebut, maka salah satu cara untuk meminimalisir kandungan aflatoksin produk pangan adalah menetapkan batas maksimumnya. Batas maksimum aflatoksin yang dapat dikonsumsi manusia sebesar $4-30 \mathrm{ppb}(\mu \mathrm{g} / \mathrm{kg})$ (Udomkun et al., 2017). Namun, setiap negara memiliki batas maksimum aflatoksin yang berbeda-beda. Di Indonesia, menurut Keputusan Kepala BPOM - No. HK.00.05.1.4507 (2004), batas maksimum untuk aflatoksin B1 sebesar 20 $\mathrm{ppb}$, dan untuk aflatoksin total sebesar $35 \mathrm{ppb}$. Australia menetapkan batas maksimum aflatoksin total sebesar 5 ppb untuk seluruh produk pangan, kecuali kacang tanah dengan batas maksimum aflatoksin total yang lebih tinggi, yaitu sebesar 15 ppb (Banwart, 1989). Untuk Eropa, pembatasan maksimum aflatoksin sangatlah ketat, yaitu tidak lebih dari $2 \mathrm{ppb}$ aflatoksin B1 dan 4 ppb untuk aflaktosin total (European Commission-EC., 2010). Sementara, regulasi Amerika (US Food and Drug Administration) menyatakan bahwa batas aman aflatoksin total sebesar $20 \mathrm{ppb}$ (Wu, 2006). Secara umum, berdasarkan data US FDA tersebut dapat dikatakan bahwa produk berbasis kacang tanah sebaiknya memiliki kandungan total aflatoksin tidak lebih 20 ppb. Dengan kata lain, produk memiliki kandungan aflatoksin B1, B2, G1, G2 masing-masing sebesar maksimal 5 ppb. Namun, ketatnya regulasi aflatoksin di negara-negara lain (Australia dan Eropa) akan mempengaruhi perdagangan internasional produk pangan Indonesia, mengingat peraturan aflatoksin dalam negeri Indonesia yang lebih longgar. Berkaitan dengan hal tersebut, penyesuaian aflatoksin maksimum produk pangan Indonesia terhadap regulasi internasional juga perlu dikaji untuk mendongkrak perdagangan di pasar global, di samping pasar regional.

Dengan mempertimbangkan keterbatasan UKM yang telah disebutkan di depan, maka sangat esensial bila dilakukan penyusunan Prosedur Opersional Baku (POB) pada UKM Bimaram dengan mengacu pada parameter kuantifikasi proses produksi serta keamanan produk kacang sangrai yang dihasilkan. Diharapkan dengan penyusunan POB ini, produk kacang sangrai Bimaram dapat konsisten serta memenuhi kualifikasi berdasarkan mutu dan kandungan aflatoksinnya. Guna menganilis POB yang telah disusun dan mulai diterapkan di UKM Bimaram, diperlukan metode pengujian, yang mencakup uji sensoris, kadar air, dan kandungan aflatoksin B1 terhadap produk yang dihasilkan.

\section{METODE PENELITIAN Bahan}

\section{Bahan Yang Digunakan dalam Penyusunan POB}

Bahan utama yang digunakan sebagi obyek penyusunan $\mathrm{POB}$ adalah kacang sangrai produksi UKM Bimaram. Untuk gambaran singkatnya, UKM Bimaram adalah perkumpulan wanita yang didirikan di Dusun Banombo B, Pucanganom, Rongkop, Gunungkidul. UKM Bimaram bergerak dalam bidang produksi olahan pangan berbasis kacang tanah. Produk 
utamanya adalah kacang tanah sangrai (kacang oven) dan enting-enting kacang. Dari sisi penerimaan konsumen, produk UKM Bimaram terutama kacang sangrai sangat diminati oleh masyarakat, baik itu masyarakat sekitar, ataupun konsumen di luar Gunungkidul. Walaupun begitu, kuantifikasi dalam proses produksi masih dilakukan berdasarkan pengalaman, feeling, ataupun pengukuran dengan alat-alat yang tidak baku dan tidak bisa diaplikasikan sebagai standar secara umum, seperti sotel, gayung, dan centong.

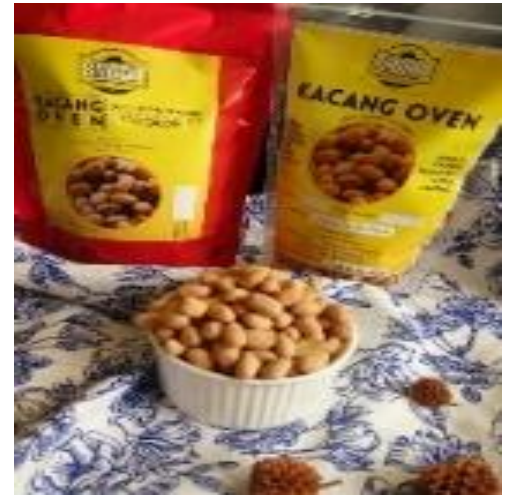

Gambar 1. Produk Kacang Sangrai (Kacang Oven) UKM Bimaram

Untuk tujuan standarisasi proses produksi, UKM Bimaram diberikan pendampingan penyusunan $\mathrm{POB}$ serta bantuan peralatan dan bahan untuk mendukung penyusunan $\mathrm{POB}$ oleh Balai Penelitian Teknologi Bahan Alam (BPTBA) LIPI melalui program Prioritas Nasional. Adapun peralatan dan bahan tersebut adalah timbangan digital, sendok takar, gelas ukur, plastik polipropilen, baskom aluminium, baskom stainless steel, nampan plastik, nampan aluminium, kotak isolator panas (cooler box), kemasan standing pouch plastik dan aluminium foil, sarung tangan plastik, serta hand sealer

\section{Bahan yang Digunakan dalam Pengujian Mutu dan Keamanan Produk}

Bahan-bahan yang digunakan dalam pengujian mutu dan keamanan produk adalah silika gel dari Bratachem, borang uji kesukaan, metanol pro analisis dari Merck Millipore, kertas saring Whatman No.1 dari GE Healthcare, kit ELISA Romer AgraQuant Total Aflatoxin Assay 4/40, dan air destilasi.

\section{Prosedur Penelitian}

\section{Penyusunan Prosedur Operasional Baku (Standard Operating Procedure)}

Kegiatan standardisasi produksi kacang sangrai dilakukan bersama-sama seluruh anggota UKM di UKM Bimaram dengan melibatkan narasumber peneliti-peneliti Balai Penelitian Teknologi Bahan Alam (BPTBA) LIPI dengan kepakaran teknologi pangan, teknik kimia, tata boga, serta bioteknologi. Tahapan penyusunan Prosedur Operasional Baku (POB), meliputi:

\section{a. Kajian proses produksi}

Informasi mengenai proses produksi didapatkan dari UKM Bimaram melalui wawancara dan komunikasi terhadap anggota UKM serta pengamatan proses produksi secara langsung. Informasi / data sekunder juga diperlukan, yang meliputi jurnal-jurnal ataupun referensi lain.

\section{b. Penentuan alur produksi}

Setelah dilakukan pengkajian seluruh proses produksi, tahap selanjutnya adalah pembuatan alur produksi. Alur produksi disusun secara runtut dan sistematis dari hulu (raw materia) ke hilir (produk). Alur produksi mencakup sub-sub kegiatan produksi, yang selanjutnya disebut titik proses. 


\section{c. Penjabaran setiap titik proses}

Setiap titik proses (sub kegiatan produksi) perlu dibuat detail proses dan diusahakan untuk dibuatkan standardisasinya yang mencakup kuantitas (pengukuran), kualitas, ataupun kedua-keduanya. Peralatan yang digunakan juga dijabarkan secara detail. Selain itu, sasaran (indikator/hasil) untuk setiap titik proses juga perlu dijabarkan.

\section{d. Penyusunan Prosedur Operasional Baku (POB)}

Langkah selanjutnya adalah penyusunan Prosedur Operasional Baku (POB) yang meliputi pencatatan alur produksi, data alat, data bahan, dan sasaran hasil tiap titik proses. Proses penyusunan POB dilakukan tanpa mengubah prosedur dan kuantitas yang biasa dilakukan oleh UKM. POB memfasilitasi agar alur produksi dapat tercatat dan menjadikan bagian-bagian produksi dapat dikuantifikasi secara standar (baku), serta memperbaiki titik proses yang perlu diperbaiki. Penyusunan POB ini dilakukan dengan melibatkan seluruh anggota UKM didampingi narasumber peneliti Balai Penelitian Teknologi Bahan Alam (BPTBA) LIPI.

\section{e. Penerapan Prosedur Operasional Baku (POB) di UKM Bimaram}

Karena $\mathrm{POB}$ yang telah disusun tidak mengubah prosedur dan kuantitas yang biasa dilakukan oleh UKM, maka penerapannya tidak menimbulkan kesulitan bagi seluruh anggota UKM. Sebagai pendampingan dan pengawasan terhadap penerapan POB, maka dilakukan praktik bersama antara narasumber peneliti BPTBA LIPI dengan seluruh anggota UKM berdasar POB yang telah disusun. Setelah UKM dirasa layak dan paham dalam menjalankan semua detail POB, maka UKM dapat menjalankan proses produksi secara mandiri.

\section{Pengujian Mutu dan Keamanan Kacang Sangrai}

Penerapan POB akan mempengaruhi mutu dan keamanan produk kacang sangrai yang dihasilkan. Parameter-parameter uji yang memberikan interpretrasi sebagai parameter mutu dan keamanan produk, antara lain adalah kadar air, sifat sensoris, serta kandungan aflatoksin B1. Kadar air merupakan parameter uji yang berkaitan dengan tingkat kerenyahan produk. Karena pada produk makanan seperti kacang sangrai, semakin rendah kadar air maka semakin renyah produk tersebut, dan sebaliknya. Sifat sensoris merupakan parameter uji yang berkaitan tingkat kesukaan konsumen secara organoleptik (sensoris). Kedua parameter uji tersebut, yaitu kadar air dan sifat sensoris mewakili mutu produk dan akan mempengaruhi penerimaan pasar (konsumen). Sementara kandungan aflatoksin B1 merupakan parameter yang berkaitan dengan keamanan produk, termasuk produk berbasis kacang-kacangan. Parameter tersebut berkaitan dengan penerimaan pasar dari segi keamanan pangan yang mana telah disebutkan bahwa setiap negara menetapkan nilai ambang batas aflatoksin yang berbeda-beda.

\section{a. Kadar air}

Kadar air bahan dideterminasi melalui pengujian kadar air thermogravimetri menurut AOAC, 950.46 (AOAC, 1995). Komoditas yang diuji kadar airnya adalah kacang mentah dan kacang sangrai sebelum diterapkan POB dan setelah diterapkan POB. Sampel kacang terlebih dahulu dilembutkan (diperkecil ukurannya)dengan mortar dan alu. Sampel kemudian ditimbang sebanyak 1 gram dan dimasukkan ke dalam krus porselen yang sebelumnya telah dilakukan pengovenan pada suhu $105^{\circ} \mathrm{C}$ selama 3 jam dan ditimbang berat kosong krusnya. Krus porselen berisi sampel kemudian dimasukkan ke dalam oven $105^{\circ} \mathrm{C}$ selama sehari semalam, kemudian dilakukan penimbangan setelah sebelumnya didinginkan pada desikator yang berisi silika gel selama 15 menit. Penimbangan dilanjutkan kembali sampai bobot konstan (selisih antar penimbangan \pm 0,002 gram) dengan selisih waktu antar penimbangan adalah 3 jam. 


\section{b. Sifat sensoris}

Pengujian sensoris dilakukan terhadap produk kacang sangrai sebelum penerapan POB ataupun setelah penerapan POB. Uji sensoris dilakukan melalui 21 panelis tak terlatih melalui pengukuran tingkat kesukaan panelis terhadap produk. Scoring test untuk menggambarkan kesukaan dinyatakan dengan nilai $1-7$, dengan nilai $1=$ sangat tidak suka, 2 = tidak suka, 3 = agak tidak suka, 4 = biasa saja, $5=$ agak suka, $6=$ suka, dan $7=$ sangat suka. Parameter yang dinilai adalah rasa, aroma, dan kekerasan.

\section{c. Kandungan aflatoksin B1}

Deteksi aflatoksin B1 menggunakan metode ELISA (Enzyme-Linked Immunosorbent Assay) - AgraQuant Aflatoxin assay merujuk pada Ubwa et al., 2014. Komoditas yang diuji adalah kacang mentah, kacang jemur (setengah kering), dan kacang sangrai setelah penerapan POB. Sampel kacang dihancurkan (diperkecil ukurannya) sehingga bisa disaring dengan ayakan 20 mesh. Kemudian sampel diekstrak menggunakan pelarut metanol $70 \%$ dengan komposisi 1:5 (b/v) dan ditutup rapat. Campuran ekstraksi digoyang dan digojog selama 3 menit dan kemudian didiamkan sebentar. Campuran disaring menggunakan filter Whatman no.1. Filtrat yang didapat kemudian digunakan untuk analisis aflatoksin B1 menggunakan ELISA reader.

Analisis aflatoksin menggunakan Kit ELISA Romer AgraQuant Total Aflatoxin Assay 4/40 berdasar prinsip ikatan antigen-antibodi. Sebanyak $100 \mu \mathrm{L}$ sampel yang diekstraksi atau standar afltatoksin $(0,10,20$, dan 40 ppb) dicampurkan dengan $200 \mu \mathrm{L}$ enzim-terkonjugasi aflatoksin kemudian $100 \mu \mathrm{L}$ campuran dipindahkan ke mikroplat berlapis antibodi dan diinkubasi selama 15 menit pada suhu ruang. Setelah inkubasi, campuran dibuang dan dilanjutkan dengan pencucian menggunakan air destilasi sebanyak lima kali. Setelah itu, mikroplat dikeringkan dengan cara mikroplat dipukul dengan posisi terbalik di atas tumpukan tisu. Setelah kering, substrat enzim ditambahkan ke mikroplat sebanyak $100 \mu \mathrm{L}$ dan diinkubasi selama 5 menit hingga menghasilkan warna biru. Sebanyak $100 \mu$ larutan stop ditambahkan untuk mengubah warna dari biru menjadi kuning. Mikroplat diukur secara optikal menggunakan ELISA reader dengan filter absorbansi $450 \mathrm{~nm}$ dan filter diferensial $630 \mathrm{~nm}$. Absorbansi yang diperoleh dikonversi menjadi kandungan aflatoksin melalui kurva standar AgraQuant Total Aflatoksin Assay 4/40 dengan rumus sebagai berikut :

$$
\begin{aligned}
& \mathrm{Y}=\mathrm{aX}+\mathrm{b} \text { (Ubwa et al., 2014) } \\
& \text { dimana : } \\
& \mathrm{Y} \quad=\text { kandungan aflatoksin (ppb) } \\
& \mathrm{X} \quad=\text { absorbansi } \\
& \mathrm{A} \quad=\text { konstanta } \\
& \mathrm{B} \quad=\text { koefisien regresi. }
\end{aligned}
$$

\section{d. Analisis statistik}

Data yang didapatkan diolah secara statistik menggunakan SPSS 12 (Wijaya dan Budiman, 2017). Untuk mengetahui signifikansi hasil dengan adanya variasi dua perlakuan yaitu sebelum penerapan POB dan setelah penerapan POB, maka digunakan uji T dua sampel independen dengan taraf kepercayaan yang digunakan sebesar 95\%. Uji korelasi Kendall's tau-b digunakan untuk menganilisis signifikansi pengaruh (hubungan) dua perlakuan tersebut terhadap sifat dan mutu komoditas kacang. 


\section{HASIL DAN PEMBAHASAN}

\section{Prosedur Operasional Baku (POB) yang Disusun}

Alur proses produksi yang terdapat dalam draft POB divisualisasikan oleh Gambar 2.

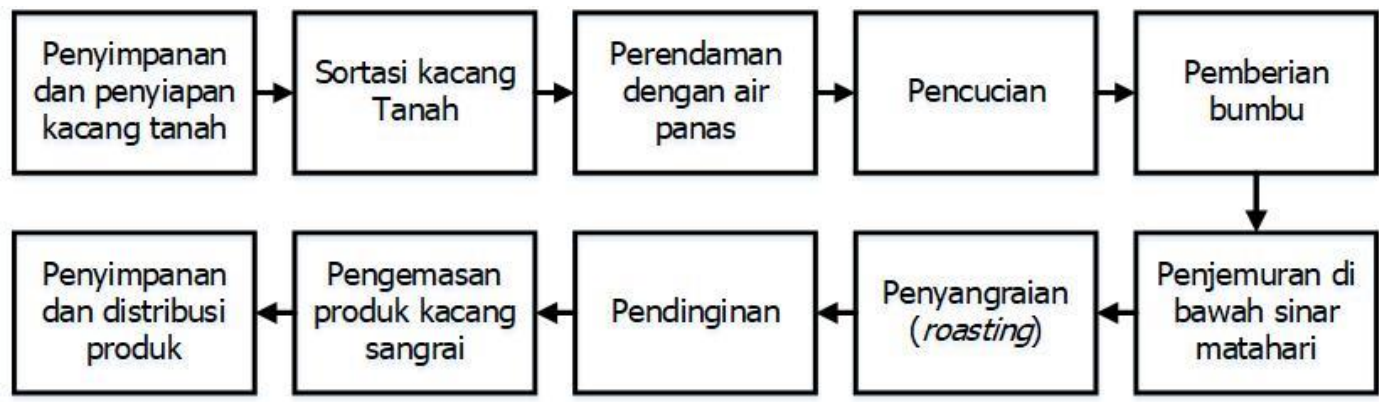

Gambar 2. Alur Proses Produksi Kacang Sangrai

Detail tiap titik proses dijelaskan sebagai berikut:

\section{a. Penyimpanan dan penyiapan bahan baku (kacang tanah)}

Kacang tanah yang didapatkan dari petani lokal Dusun Banombo (ketika panen) atau didapatkan dari pasar lokal (ketika tidak panen) merupakan kacang tanah kupas kulit dalam kondisi kering. Kacang disimpan dalam karung plastik ataupun plastik polietilen (PE) tipis dan polipropilen (PP) dalam kondisi kering dan sejuk dengan tujuan untuk menghindari kontaminasi jamur, hewan, dan serangga. Penyimpanan dengan kondisi tersebut dapat menekan kontaminasi aflatoksin sebesar 3,9 ppb selama 4 bulan (Ginting, 2006). Mohammed dan Chala (2014) juga menyatakan bahwa bahan penyimpan yang memiliki sifat menghalangi uap (vapor barrier) akan membantu mengurangi tingkat kondensasi dalam produk kacang.

Bahan baku disimpan sedemikian rupa (berurutan) sehingga dalam penyiapan dan pergerakan bahan baku dapat diaplikasikan prinsip rotasi First-in, First-out (FIFO). Sistem rotasi ini memungkinkan bahwa kacang tanah yang disimpan dulu akan dipergunakan untuk produksi terlebih dahulu. Konsep rotasi ini sangat mendukung dalam hal kualitas dan keamanan pangan karena sangat potensial untuk meminimalkan patogen (US FDA, 2006). Konsep ini juga memberikan manfaat yang positif bagi anggota UKM agar terbiasa dalam memastikan sanitasi dan keamanan bahan baku, mengorganisasi stok barang/inventori, serta membiasakan pergerakan bahan baku yang sistematis (Susanto et al., 2017).

\section{b. Sortasi kacang tanah}

Kacang tanah yang diadakan oleh UKM Bimaram merupakan kacang tanah hasil sortasi tingkat petani (kacang tanah pilihan), namun UKM berusaha melakukan sortasi kembali untuk memastikan kualitas dan keamanannya. Parameter kacang yang digunakan dalam proses pengapkiran yaitu warna, bentuk, ukuran, dan kenampakan lain. Kacang yang memiliki warna yang tidak seragam dengan kacang yang lainnya dikarenakan terdapat jamur atau faktor lain, serta kacang dengan ukuran kecil dan bentuk kisut (ukuran dan bentuk tidak seragam) diusahakan untuk diapkir. Parameter lain adalah kacang yang sudah terdapat bubuk (powder) juga diapkir.

Tahap sortasi tersebut merupakan salah satu metode untuk meminimalkan aflatoksin pada kacang. Udomkun et al. (2017) menyatakan hal yang serupa bahwa aflatoksin dapat diminimalkan bahkan sampai $95 \%$ pengurangan melalui tahap sortasi melalui diferensiasi fisik berdasar beberapa parameter, yaitu warna, bentuk, ukuran, dan densitas. Kontaminasi jamur penghasil aflatoksin menyebabkan penurunan densitas kacang, yang dipicu karena pertumbuhan jamur memanfaatkan endosperma kacang sebagai substrat sehingga endosperma berubah menjadi berbubuk dan densitasnya akan berkurang. 


\section{c. Perendaman dengan air panas}

Kacang tanah yang telah disortasi, kemudian dilakukan perendaman dengan air panas suhu $80-90^{\circ} \mathrm{C}$ selama 20 menit. Perendaman air panas dilakukan dengan perbandingan komposisi kacang dan air sebesar kurang lebih 1:2 (b/v). Tujuan dari perendaman ini adalah untuk melakukan penetrasi air dan membuka pori-pori kulit ari kacang, sehingga mempercepat pembumbuan (mempercepat transfer massa bumbu dari pemukaan kulit ari ke endosperma) dengan harapan kacang sangrai yang dihasilkan lebih berasa. Selama tahap perendaman, bila ada kacang yang mengapung maka kacang tersebut diapkir. Hal tersebut dilakukan dengan pertimbangan bahwa kacang yang mengapung memiliki densitas rendah, dan besar kemungkinan dikarenakan kontaminasi jamur. Sementara, ciri-ciri kacang hasil perendaman ini adalah kulit ari kacang yang sedikit licin dan melar.

\section{d. Pencucian}

Kacang yang telah direndam kemudian dicuci dengan air kran (air PDAM) pada suhu kamar $\left(28-30^{\circ} \mathrm{C}\right)$ sebanyak 2-3 kali kemudian ditiriskan.

\section{e. Pemberian bumbu}

Bumbu yang digunakan untuk kacang sangrai dikuantifikasi dulu menggunakan timbangan digital dan sendok takar. Bumbu dihaluskan dan kemudian dicampurkan ke dalam kacang sampai merata dan meresap.

\section{f. Penjemuran di bawah sinar matahari}

Kacang yang telah dibumbui kemudian dijemur di bawah sinar matahari dengan alas nampan yang terbuat dari plastik ataupun nampan stainless steel. Tujuan dari tahap ini adalah untuk mendapatkan kacang setengah kering yang ditandai dengan berkurangnya kadar air pada kacang, sehingga beban pengeringan pada tahap roasting (penyangraian) tidak terlalu besar. Penjemuran diusahakan untuk tidak menggunakan alas nampan (wadah) dari bambu atau kayu untuk menghindari kontaminasi jamur. Jika musim panas (kemarau) penjemuran setengah kering membutuhkan waktu sekitar setengah sampai satu hari. Sementara pada saat musim penghujan, waktu yang diperlukan lebih lama, yaitu dua sampai dua setengah hari.

\section{g. Penyangraian (roasting)}

Penyangraian dilakukan di atas wajan gerabah dengan media pasir putih (pasir pantai Gunungkidul). Pasir yang digunakan sebelumnya dibersihkan, dicuci, dan dikeringkan terlebih dahulu. Rasio pasir dan kacang setengah kering yang digunakan dalam proses roasting agar kacang tanah tertutupi dengan pasir adalah 3/2 (b/b). Penyangraian dilakukan di atas kompor dengan api kecil dengan cara diaduk-aduk agar kulit ari kacang tidak gosong. Setelah dirasa kering (ditandai dengan pengadukan yang ringan karena air dalam kacang teruapkan, dan waktu yang dibutuhkan kurang lebih 10 menit), maka proses sangrai dihentikan. Kemudian, dilakukan proses pemisahan antara kacang dan pasir dengan cara diayak dengan ayakan bambu yang kering dan bersih, serta pasir bisa lolos ke bawah.

\section{h. "Pengovenan"}

Kacang yang terpisah dengan pasir dan masih panas dimasukkan ke dalam wadah tertutup yang bersifat isolator panas dan terlapisi kain blacu /kain mori bersih. Setelah itu kain dan wadah masing-masing ditutup. Proses ini dijuluki oleh anggota UKM sebagai proses "pengovenan". Tujuan dari proses ini adalah meningkatkan kematangan kacang sangrai tanpa memberikan efek browning (gosong). Waktu yang dibutuhkan untuk pengovenan adalah 5 menit.

\section{i. Pendinginan}

Kacang sangrai kemudian didinginkan dengan cara diangin-angin agar suhu kacang sama dengan suhu kamar. Waktu yang dibutuhkan untuk pendinginan kurang lebih 7 menit. Yang perlu diperhatikan adalah waktu pendinginan tidak boleh terlalu lama agar kacang tidak melempem. 


\section{j. Pengemasan}

Kacang sangrai dikemas dalam kemasan plastik atau aluminium foil stand up pouch yang telah dilengkapi label. Untuk memasukkan kacang dalam kemasan digunakan sendok atau sarung tangan plastik untuk menjaga sanitasi dan higienitas. Kemasan kemudian diseal menggunakan hand sealer.

\section{k. Penyimpanan dan distribusi produk}

Setiap proses produksi, kacang sangrai yang telah diproduksi diberi kode produksi agar dapat menelusur produk jika suatu waktu terdapat kejadian akibat produk ataupun komplain dari pembeli. Inventori dan penyimpanan produk kacang oven dilakukan secara berurutan yang memungkinkan terjadi sitem rotasi First-in, First-out (FIFO), artinya kacang sangrai yang diproduksi dan disimpan dulu, juga akan dijual dan distribusikan lebih dahulu.

Untuk detail spesifikasi peralatan dan bahan serta sasaran hasil tiap titik proses dijelaskan dalam Tabel 1.

Tabel 1. Spesifikasi Peralatan dan Bahan serta Sasaran Hasil Tiap Titik Proses Produksi

\begin{tabular}{|c|c|c|c|}
\hline No. & Titik Proses & Spesifikasi Peralatan dan Bahan & Sasaran Hasil \\
\hline 1. & $\begin{array}{l}\text { Penyimpanan dan } \\
\text { Penyiapan bahan } \\
\text { baku }\end{array}$ & $\begin{array}{l}\text { Peralatan : } \\
\text { - Karung plastik dan plastik } \\
\text { polipropilen }\end{array}$ & $\begin{array}{l}\text { Kacang tanah yang disimpan } \\
\text { terlebih dahulu, otomatis } \\
\text { akan dipergunakan untuk } \\
\text { produksi terlebih dahulu }\end{array}$ \\
\hline 2. & Sortasi kacang tanah & & $\begin{array}{l}\text { Kacang tanah dengan } \\
\text { bentuk, ukuran, dan warna } \\
\text { yang seragam dengan tidak } \\
\text { berbubuk dan berjamur }\end{array}$ \\
\hline 3. & $\begin{array}{l}\text { Perendaman dengan } \\
\text { air panas. }\end{array}$ & $\begin{array}{l}\text { Bahan : } \\
\text { - Air PDAM } \\
\text { Peralatan : } \\
\text { - Baskom berbahan stainless } \\
\quad \text { stee/ atau aluminium }\end{array}$ & $\begin{array}{l}\text { Adanya penetrasi dalam } \\
\text { kacang tanah (endosperma) } \\
\text { yang ditandai dengan kulit } \\
\text { ari yang sedikit licin dan } \\
\text { agak melar. Dalam proses } \\
\text { perendaman, apabila } \\
\text { terdapat kacang yang } \\
\text { mengapung maka dilakukan } \\
\text { pengapkiran. }\end{array}$ \\
\hline 4. & Pencucian & $\begin{array}{l}\text { Bahan : } \\
\text { - Air PDAM } \\
\text { - Baskom } \\
\text { - Saringan aluminium atau } \\
\text { plastik }\end{array}$ & Kacang yang sudah bersih. \\
\hline 5. & Pemberian bumbu & $\begin{array}{l}\text { Bahan : } \\
\text { - Bumbu - bumbu } \\
\text { Peralatan : } \\
\text { - Timbangan digital kapasitas } \\
5 \mathrm{~kg} \\
\text { - Serangkai sendok takar } \\
\text { - Cobek dan muntu } \\
\text { - Baskom }\end{array}$ & $\begin{array}{l}\text { Kacang yang telah terbumbui } \\
\text { dengan meresap. }\end{array}$ \\
\hline
\end{tabular}




\begin{tabular}{|c|c|c|c|}
\hline 6. & $\begin{array}{l}\text { Penjemuran di } \\
\text { bawah sinar } \\
\text { matahari }\end{array}$ & $\begin{array}{l}\text { Peralatan : } \\
\text { - Nampan plastik atau } \\
\text { stainless steel. Sebisa } \\
\text { mungkin dihindari untuk } \\
\text { menggunakan alas berbahan } \\
\text { kayu atau bambu }\end{array}$ & $\begin{array}{l}\text { Kacang bumbu dengan } \\
\text { kondisi setengah kering. }\end{array}$ \\
\hline 7. & $\begin{array}{l}\text { Penyangraian } \\
\text { (roasting) }\end{array}$ & $\begin{array}{l}\text { Bahan : } \\
\text { - Pasir putih dengan maksimal } \\
\text { penggunaan untuk roasting } \\
\text { adalah } 3 \text { kali, dengan dicuci } \\
\text { kembali bila ingin dipakai } \\
\text { Peralatan : } \\
\text { - Wajan berbahan gerabah } \\
\text { - Kompor gas } 2 \text { tungku } \\
\text { dengan api sedang } \\
\text { - Saringan bambu (irig) dalam } \\
\text { keadaan bersih dan kering. }\end{array}$ & $\begin{array}{l}\text { Kacang tanah yang ringan } \\
\text { jika diaduk atau diambil, } \\
\text { dengan warna yang sedikit } \\
\text { berubah (sedikit cokelat), } \\
\text { namun tidak gosong. } \\
\text { Kematangan belum } \\
\text { sempurna karena masih } \\
\text { terdapat tekstur lunak jika } \\
\text { diicip. }\end{array}$ \\
\hline 8. & "Pengovenan" & $\begin{array}{l}\text { Peralatan : } \\
\text { - Kardus atau kotak isolator } \\
\text { panas (cooler box) } \\
\text { - Kain mori yang bersih }\end{array}$ & $\begin{array}{l}\text { Kacang tanah yang lebih } \\
\text { ringan jika diambil dengan } \\
\text { kematangan yang mendekati } \\
\text { sempurna karena renyah dan } \\
\text { tidak lunak jika diicip. }\end{array}$ \\
\hline 9. & Pendinginan & $\begin{array}{l}\text { Peralatan : } \\
\text { - Nampan plastik atau } \\
\text { aluminium sebagai wadah } \\
\text { kacang sangrai yang } \\
\text { matang. }\end{array}$ & $\begin{array}{l}\text { Suhu kacang sangrai yang } \\
\text { sama dengan suhu ruang } \\
\text { sehingga kacang siap untuk } \\
\text { dikemas. }\end{array}$ \\
\hline 10. & Pengemasan & $\begin{array}{l}\text { Bahan : } \\
\text { - Kemasan standing pouch } \\
\text { plastik atau aluminium foil } \\
\text { - Sarung tangan plastik } \\
\text { Peralatan : } \\
\text { - Hand sealer } \\
\text { - Mesin print expired date }\end{array}$ & $\begin{array}{l}\text { Kacang sangrai yang telah } \\
\text { dikemas dan diberi kode } \\
\text { produksi untuk pencatatan } \\
\text { dan penelusuran produk. }\end{array}$ \\
\hline 11. & $\begin{array}{l}\text { Penyimpanan dan } \\
\text { distribusi dan } \\
\text { penjualan produk }\end{array}$ & $\begin{array}{l}\text { Peralatan : } \\
\text { - Kardus karton } \\
\text { - Lemari etalase }\end{array}$ & $\begin{array}{l}\text { Kacang sangrai yang } \\
\text { diproduksi terlebih dahulu, } \\
\text { otomatis akan dikeluarkan, } \\
\text { didistribusikan, dan dijual } \\
\text { terlebih dahulu }\end{array}$ \\
\hline
\end{tabular}

\section{Hasil Pengujian Mutu dan Kandungan Aflatoksin \\ a. Kadar air}

Kadar air diujikan untuk komoditas kacang mentah dan produk kacang sangrai, baik sebelum dan sesudah diaplikasikan POB dalam proses produksi dengan hasil uji yang ditunjukkan oleh Tabel 2. 
Tabel 2. Kadar air pada Komoditas Kacang Mentah dan Produk Kacang Sangrai sebelum dan setelah Penerapan POB.

\begin{tabular}{cccc}
\hline Komoditas & \multicolumn{2}{c}{ Kadar air (\%) } & $\begin{array}{c}\text { Korelasi penerapan POB } \\
\text { terhadap komoditas }\end{array}$ \\
\cline { 2 - 3 } & $\begin{array}{c}\text { Sebelum } \\
\text { penerapan POB }\end{array}$ & $\begin{array}{c}\text { Setelah } \\
\text { penerapan POB }\end{array}$ & \\
\hline Kacang mentah & $8,67 \pm 0,04^{\mathrm{a}}$ & $9,06 \pm 0,07^{\mathrm{b}}$ & signifikan $(\mathrm{p}<0,05 ; \mathrm{r}=0,775)$ \\
Kacang sangrai & $4,31 \pm 0,16^{\mathrm{a}}$ & $4,58 \pm 0,21^{\mathrm{a}}$ & $\begin{array}{c}\text { tidak signifikan }(\mathrm{p}>0,05 ; \\
\mathrm{r}=0,430)\end{array}$ \\
\hline
\end{tabular}

Keterangan: nilai menunjukkan rata-rata dan standar erornya. Superskrip yang berbeda pada baris yang sama menunjukkan perbedaan yang signifikan $(p<0,05)$ berdasar hasil uji $T$.

Seperti yang ditunjukkan oleh Tabel 2, perbedaan kadar air yang signifikan pada komoditas kacang mentah sebelum dan sesudah penerapan POB, bukan dikarenakan pengaruh penerapan $\mathrm{POB}$. Melainkan, hal tersebut menunjukkan bahwa kacang mentah yang didapat oleh UKM Bimaram melalui suplai dari petani, pasar, ataupun pedagang memiliki spesifikasi kadar air yang berbeda.

Kadar air kacang tanah mentah dipengaruhi oleh suhu, kelembaban, aktivitas respirasi biji, serangga dan cendawan, faktor ketinggian diatas permukaan laut dan curah hujan di setiap kota. Kadar air kacang tanah mentah berkisar 8,67-9,06\% sehingga dapat dinyatakan bahwa cara penanganan pasca panen kacang (pengeringan matahari) sudah dilakukan secara layak. Berdasarkan Standar Nasional Indonesia (SNI) 01-3921-1995, kadar air kacang tanah biji berkisar antara 6-8\%.

Namun dengan adanya pengolahan kacang sangrai, baik yang diproduksi sebelum penerapan $\mathrm{POB}$ maupun setelah penerapan $\mathrm{POB}$ dihasilkan kadar air dengan perbedaan yang tidak begitu signifikan untuk keduanya. Hasil uji korelasi juga menguatkan bahwa penerapan POB tidak berpengaruh terhadap kadar air kacang sangrai yang dihasilkan. Hal ini juga menunjukkan tidak ada perbedaan yang berarti antara POB yang disusun dengan prosedur produksi yang telah biasa dilakukan UKM Bimaram. POB yang disusun tidak mengubah langkah kerja, namun mencatat langkah tesebut dan menyajikannya lebih sistematis, terukur standar dengan dilengkapi spesifikasi material dan peralatan yang digunakan. Kadar air yang hampir sama pada kacang sangrai, baik sebelum dan setelah diterapkan POB mengindikasikan kedua produk memiliki tingkat kerenyahan yang hampir sama. Hal ini dapat dikonfirmasi melalui hasil uji sensoris dengan parameter kekerasan.

\section{b. Karakteristik sensoris}

Karakteristik sensoris yang dianalisis terhadap produk kacang sangrai hasil produksi sebelum penerapan $\mathrm{POB}$ dan setelah penerapan $\mathrm{POB}$, ditunjukkan oleh Tabel 3.

Tabel 3. Karakteristik Sensorik pada Produk Kacang Sangrai sebelum dan setelah Penerapan POB.

\begin{tabular}{|c|c|c|c|}
\hline \multirow[t]{2}{*}{ Parameter } & \multicolumn{2}{|c|}{ Tingkat Kesukaan } & \multirow{2}{*}{$\begin{array}{l}\text { Korelasi penerapan POB terhadap } \\
\text { komoditas }\end{array}$} \\
\hline & $\begin{array}{c}\text { Sebelum } \\
\text { penerapan POB }\end{array}$ & $\begin{array}{c}\text { Setelah } \\
\text { penerapan POB }\end{array}$ & \\
\hline Rasa & $5,90 \pm 0,19^{a}$ & $6,10 \pm 0,23^{a}$ & tidak signifikan $(p>0,05 ; r=0,159)$ \\
\hline Aroma & $5,14 \pm 0,25^{a}$ & $5,76 \pm 0,14^{b}$ & signifikan $(p<0,05 ; r=0,284)$ \\
\hline Kekerasan & $5,67 \pm 0,25^{a}$ & $6,24 \pm 0,14^{a}$ & tidak signifikan $(p>0,05 ; r=0,250)$ \\
\hline
\end{tabular}

Keterangan: nilai menunjukkan rata-rata dan standar erornya. Superskrip yang berbeda pada baris yang sama menunjukkan perbedaan yang signifikan $(p<0,05)$ berdasar hasil uji $T$. 
Dari Tabel 3, terlihat bahwa tingkat kesukaan panelis terhadap produk kacang sangrai tergolong tinggi dengan kesukaan untuk semua parameter bernilai lebih dari 5 (agak suka), bahkan sebagian besar mendekati nilai 6 (suka). Penerapan POB terhadap komoditas kacang sangrai memperbaiki karakteristik organoleptik dengan meningkatkan tingkat kesukaan panelis, walaupun perbedaannya tidak signifikan. Untuk parameter aroma, perbedaannya signifikan. Aroma yang dimaksud adalah keberadaan aroma langu pada produk. Nilai aroma yang lebih tinggi pada produk kacang sangrai setelah diterapkan POB mengindikasikan berkurangnya aroma langu pada produk. Hal tersebut berkaitan dengan proses perendaman air panas, pencucian, dan proses sangrai yang terukur suhu, bahan, maupun peralatannya. Sementara itu, uji korelasi menunjukkan penerapan $\mathrm{POB}$ tidak berpengaruh signifikan terhadap karakteristik sensorik secara keseluruhan, kecuali juga untuk parameter aroma. Pengaruh yang tidak signifikan tersebut menandakan bahwa POB yang disusun tidak mengubah secara signifikan langkah proses produksi yang selama ini dibuat.Peningkatan nilai sensorik melalui penerapan POB juga ditelaah dan dipelajari pada produk keripik pisang (Haryanto et al., 2013). Pada penelitian tersebut dinyatakan bahwa parameter rasa, warna, dan kerenyahan mengalami peningkatan yang signifikan melalui penerapan $\mathrm{POB}$, yaitu nilai parameter rasa meningkat dari 3,3 menjadi 4; parameter warna yang meningkat dari 3,3 menjadi 4,3; serta parameter kerenyahan yang meningkat dari 3,5 menjadi 4,2.

Hasil nilai karakteristik sensorik kacang sangrai pada Tabel 3. dapat digunakan sebagai rujukan dalam pengendalian mutu bila kedepannya $\mathrm{POB}$ diterapkan secara berkesinambungan oleh UKM. Pada POB pembuatan tepung mocaf, karakteristik sensorik juga digunakan sebagai parameter kritis pengendali mutu, yang meliputi warna, kehalusan, serta bebas dari kotoran (Subagio et al., 2008). Karakteristik organoleptik merupakan pengendali mutu yang bersifat subjektif (Afrianto, 2008), sehingga penerapannya dalam pengendalian produk pangan sebaiknya dilakukan melalui panelis terlatih.

\section{c. Kandungan aflatoksin B1}

Kandungan aflatoksin B1 pada komoditas kacang mentah, kacang jemur (setengah kering), dan kacang sangrai setelah penerapan POB ditunjukkan oleh Tabel 4.

Tabel 4. Kandungan Aflatoksin B1 pada Masing-Masing Komoditas Kacang

\begin{tabular}{lc}
\hline \multicolumn{1}{c}{ Komoditas } & $\begin{array}{c}\text { Kandungan aflatoksin B1 } \\
(\mathrm{ppb})\end{array}$ \\
\hline Kacang mentah & 4,68 \\
Kacang jemur (setengah kering) & 2,78 \\
Kacang sangrai & 4,42 \\
\hline
\end{tabular}

Tabel 4 memperlihatkan bahwa kacang mentah dan kacang olahan UKM Bimaram memenuhi keamanan pangan, yaitu kandungan aflatoksin B1 di bawah batas maksimal yang diatur oleh BPOM sebesar 20 ppb dan juga masih di bawah batas maksimal aflaktoksin B1 yang diregulasi oleh FDA, sebesar 5 ppb. Kandungan aflatoksin yang rendah pada kacang mentah yang merupakan hasil sortasi menunjukkan bahwa sortasi berperan dalam meminimalkan kandungan aflatoksin pada kacang. Tren aflatoksin B1 pada kacang jemur dan kacang sangrai yang tidak berpola (fluktuatif) terhadap kacang mentah dikarenakan kandungan aflatoksin yang berbeda dalam tiap satuan kacang, sehingga mempengaruhi jumlah aflatoksin yang terambil untuk sampling analisis. Rahmianna dan Ginting (2005) melaporkan bahwa proses pengolahan, seperti penyangraian, penggorengan, dan fermentasi 
hanya dapat mengurangi kandungan aflatoksin sebesar $73-87 \%$. Dari data yang didapat terlihat bahwa proses pengolahan kacang mentah menjadi produk kacang sangrai layak dilakukan karena proses produksi tidak meningkatkan kandungan aflatoksin pada kacang.

\section{KESIMPULAN}

Draft Prosedur Operasional Baku (POB) untuk produksi kacang sangrai telah disusun dan diterapkan oleh UKM Bimaram, yang meliputi alur produksi yang mencakup titik-titik proses, spesifikasi bahan dan peralatan yang digunakan serta sasaran hasil tiap titik proses. POB yang disusun tidak mengubah prosedur produksi yang telah biasa dilakukan, namun mencatat prosedur tersebut dan menyajikannya menjadi lebih sistematis dan terukur. Hal tersebut ditunjukkan oleh hasil kadar air dan karaksteristik sensoris yang tidak berbeda signifikan pada produk kacang sangrai sebelum penerapan POB ataupun setelah penerapan POB. POB yang disusun layak untuk diterapkan oleh UKM Bimaram karena mengatur keamanan pangan mulai dari bahan baku sampai produk akhir, yang ditunjukkan dengan kadar aflatoksin B1 pada kacang mentah, kacang jemur setengah kering, dan kacang sangrai. Kandungan aflatoksin B1 untuk ketiga komoditas tersebut masih di bawah batas maksimal yang diatur oleh BPOM sebesar 20 ppb dan US FDA sebesar 5 ppb.

\section{UCAPAN TERIMA KASIH}

Penulis mengucapkan terima kasih atas program Prioritas Nasional BPTBA LIPI 2018 dalam mendukung penelitian ini. Ucapan terima kasih juga diberikan kepada Arbianti Restuti dan Sri Endartini dalam membantu analisis laboratorium. Terima kasih juga diucapkan kepada Bekti Juligani dan Taufik Kurniawan dalam membantu rekayasa dan pengoperasian peralatan UKM Bimaram selama program Prioritas Nasional BPTBA LIPI 2018.

\section{DAFTAR PUSTAKA}

Afrianto, E. 2008. Pengawasan Mutu Bahan/Produk Pangan. Direktorat Pembinaan Sekolah Menengah Kejuruan, Direktorat Jenderal Manajemen Pendidikan Dasar dan Menengah, Departemen Pendidikan. Jakarta.

AOAC Methods : 965.33, 940.28. Official Methods of Analysis of AOAC International, 16th ed. 1995. The Association of Analytical Chemists.

Arya, S.S., A. R. Salve dan S. Chauhan. 2016. Peanuts as Functional Food: a Review. Journal of Food Science and Technology 53(1): 31-41.

Banwart, G.J. 1989. Basic Food Microbiology. Chapman \& Hall. New York.

BPS-Statistics Indonesia. 2017. Statistical Yearbook of Indonesia. CV. Dharmaputra. Yogyakarta.

BPS-Statistics of D.I. Yogyakarta Province. 2018. Daerah Istimewa Yogyakarta Province in Figures 2018. Sinar Baru Offset. Yogyakarta.

European Commission-EC. 2010. Commission regulation (EU) no 165/2010 of 26 February 2010, Amending Regulation (EC) no 1881/2006 Setting Maximum Levels for Certain Contaminants in Foodstuffs as Regards Aflatoxin. Official Journal of the European Union, 8e12. L 50

Gama, A.P., K. Adhikari dan D.A. Hoisington. 2018. Peanut Consumption in Malawi : an Opportunity for Innovation. Foods 7(112): 1-13.

Ginting, E. 2006. Mutu dan Kandungan Aflatoksin Biji Kacang Tanah Varietas Kancil dan Mahesa yang Disimpan dalam Beberapa Jenis Bahan Pengemas. Jurnal Agrikultura 17(3): $165-172$.

Haryanto, D., O. Nawansih, dan F. Nurainy. 2013. Penyusunan Draft Standard Operating Procedure (SOP) Pengolahan Keripik Pisang (Studi Kasus di Salah Satu Industri Rumah 
Tangga Keripik Pisang Bandar Lampung). Jurnal Teknologi Industri dan Hasil Pertanian 18 (2) : 132- 143.

Keputusan Kepala BPOM - No. HK.00.05.1.4057. 9 September 2004. Batas Maksimum Aflatoksin dalam Produk Pangan. Jakarta.

Mohammed, A. dan A. Chala. 2014. Incidence of Aspergillus Contamination of Groundnut (Arachis hypogaea L.) in Eastern Ethiopia. African Journal of Microbiology Research 8(8): 759-765.

Mulyati, A.H., H. Nasrianto, dan E. Rachmawati. 2013 . Kandungan Aflatoksin (B1, B2, G1, dan G2) pada Kacang Tanah (Arachic Hypogaea L) yang Beredar di Pasar Tradisional Jabotabek. Seminar Nasional Riset Pangan, Obat-Obatan dan Lingkungan Untuk Kesehatan. 12 November 2013: 101-112.

Purwijantiningsih, E., R. Dewanti-Hariyadi, C.C. Nurwitri, dan Istiana (alm.). 2005. Penghambatan Produksi Aflatoksin dari Aspergillus flavus oleh Kapang dan Khamir yang Diisolasi dari Ragi Tempe. Biota X(3): 146-153.

Rahaie, S., Z. Emam-Djomeh, S.H. Razavi, dan M. Mazaheri. 2010. Immobilized Saccharomyces cerevisiae as a Potential Aflatoxin Decontaminating Agent in Pistachio Nuts. Brazilian Journal of Microbiology 41: 82-90.

Rahmianna, A.A. dan E. Ginting. 2005. Kacang Tanah: Sumber Pangan Sehat dan Menyehatkan. Sinar Tani Badan Litbang Pertanian 42(3449): 1-8.

Rozalli, N.H.M., N.L. Chin dan Y.A. Yusof. 2012. Simultaneous Multiple Responses Modelling, Optimisation and Correlation of Asian Type Peanuts (Arachis Hypogaea L.) Roasting Using Response Surface Methodology. Acta Alimentaria 43(1): 142-157.

Sherif, S.O., E.E. Salama, dan M. A. Abdel-Wahhab. 2009. Mycotoxins and Child Health: The Need for Health Risk Assessment. International Journal of Hygiene and Environmental Health 212: 347-368.

Standar Nasional Indonesia (SNI) 01-3921-1995. 1995. Kacang Tanah. Badan Standardisasi Nasional. Jakarta

Subagio, A., S.W. Wiwik, Y. Witono, dan F. Fahmi. 2008. Prosedur Operasi Standar (POS) Produksi MocalMocaf Berbasis Cluster. Pemerintah Daerah Kabupaten Trenggalek.

Susanto, P.C., I.M. Murna, dan I.G.N.M. Nugraha. 2017. Produksi dan Pemasaran Produk IbM Ladrang Bawang di Desa Bongan Kabupaten Tabanan. Jurnal Paradharma 1(1): 6-16.

Ubwa, S.T., J. Abah, B.O. Atu, R.L. Tyohemba, dan J.T. Yande. 2014. Assessment of Total Aflatoxins Level of Two Major Nuts Consumed in Makurdi Benue State, Nigeria. International Journal of Nutrition and Food Sciences 3(5): 397-403.

Udomkun P., A.N. Wiredu, M. Nagle, J. Müller, B. Vanlauwe, dan R. Bandyopadhyay. 2017. Innovative Technologies to Manage Aflatoxins in Foods and Feeds and the Profitability of Application: A review. Food Control 76: 127 - 138.

U.S. Department of Health and Human Services Food and Drug Administration Center for Food Safety and Applied Nutrition, 2006, Managing Food Safety: A Regulator's Manual For Applying HACCP Principles to Riskbased Retail and Food Service Inspections and Evaluating Voluntary Food Safety Management Systems, Food and Drug Administration 5100 Paint Branch Parkway College Park, MD 20740 (Tel) 240-402-2349.

Wijaya, T. dan S. Budiman. 2017. Analisis Data Kuantitatif. Percetakan Pohon Cahaya. Yogyakarta.

Wu, F. September 2006. Mycotoxin Reduction in Bt corn: Potential Economic, Health, and Regulatory Impacts. ISB News report. 